\title{
Research of Folk Concepts in Modern Gift Packaging Design
}

\author{
Hui Chen \\ School of Arts and Media \\ Nantong Open University \\ Nantong, China \\ e-mail: 1796675198@qq.com
}

\begin{abstract}
Folk custom is the heritage of life, culture, form and perspective that a country or a group inherits. Modern gift packaging advocates "humanization". The integration of folk elements in design could effectively strengthen the cultural connotation of modern gift packaging. The paper has discussed application of folk culture, including folk pattern, folk color, the art of calligraphy and natural materials, in modern gift packaging design in order to integrate folk culture into modern gift packaging design.
\end{abstract}

Keywords-Folk custom; modern gift packaging design; “humanized" design; connotation research

\section{THE NEED OF “HUMANIZED” DESIGN IN GIFT PACKAGING}

As a type of commodity packaging, gift packaging could not only protect commodity, convey commodity information and promote the sales of commodity, but also could be a medium for communication of people's emotion or a bridge people could pass friendly messages and thus improve the taste of the gifts. With the demand of "emotion" and the design purpose of "communication", gift packaging could integrate commodity content with design form, and improve the taste of "gift". The cultural function of gift packaging is shown in the following two aspects. First, gift packaging design shows the characteristics of national culture and times; second, for the selection of packaging material, gift packaging is made of natural materials which could convey "strong and pure" friendship and the cultural connotation of "nature and harmony". With the development of technology and the progress of the times, we should constantly seek and find some memorable connotation in gift packaging. It is a lofty aesthetic taste and a spirit to pay attention to the traditional culture. We should value the deconstruction and inheritance of tradition in the exploration and pursuit of gift taste. Gift packaging design should not be limited to goods shelf and display and communication in the market, but should involve in details of life and social relations. Different from the "one-off' characteristic of general packaging, gift packaging has the characteristics of emotion communication and hand deliverance, so it needs an intriguing connotation and a refreshing charm. Therefore, "humanization" becomes the focus of gift packaging design.

\section{FOLK EXPRESSION IN MODERN GIFTING PACKAGING DESIGN}

Modern gift packaging design has a variety of expression techniques. Folk expression is one of the expression techniques. For modern gift packaging design, we could use several thousand years of historic culture for it contains rich cultural heritage and national characteristics. It is a problem worth thinking that how we can integrate folk concepts into modern gift packaging design. Modern gift packaging design could establish a kind of internal relation through the expression of graphics, text, color and other elements. In design practice, from a large number of modern gifts packaging design works, we can understand the important influence of folk concepts for packaging design. Consumers can understand profound folklore spirit in the packaging. Gift packaging design could easily produce a kind of aesthetic impression of the depth of history and culture in people's mind. In appreciation, consumers may understand and examine folklore spirit in the packaging. We can not truly know and understand profound folk concepts in gift packaging design without knowing and mastering folk spirit behind it. If we pay attention to modern gift packaging design and understand folk concepts, we may find that the trend of modern gift packing design is guided by folk concepts intentionally or unintentionally. You may think it is superficial, but its influence on gift packaging design is ubiquitous.

\section{THE DigGING OF FolK CONNOTATION IN MODERN GIFT PACKAGING DESIGN WORKS}

We carefully study modern gift packaging design works and experience folk connotation in these works. The folk connotation that we generally say refers to the cultural password of gift packaging design. It is not an outward, superficial influence, but an inner pointing that gives a specific cultural awareness to the gift packaging design work. This cultural awareness is folklore connotation. It should be the internal support for the modern gift packaging design with Chinese characteristics. Starting from the concept of folk customs, modern gift packaging design with profound folk connotation will have a permanent strength of inheritance. 
For general form of folk customs, it is an inheritance of life, culture, form and perspective that a country or a group inherits. It has three levels of meaning. First is the material level of folk customs. Second is the system level of folk customs. Third is the spiritual level of folk customs. From the surface structure of folk customs, they are unwritten popular regulations in social groups. From the deep structure of folk customs, they are original cultural awareness groups existing in people's minds. [2] Through understanding the general meaning of folk customs, we can open a design idea for the modern gift packaging design. The ultimate goal of modern gift packaging design is to communicate emotions among people and improve the taste of the gift and expect to bring good sense and feedback to the consumers. Therefore, the intensive application of folk concepts in gift packaging design could help people understand and accept modern gift packaging design. On the basis of the inheritance of folk connotation, modern gift packaging design could win recognition of the consumers through communicating emotion. Folk concepts in modern gift packaging design have a natural cultural attribute of "strong and pure" friendship, which will greatly promote the development of modern gift packaging design.

\section{THE APPLICATION OF FOLK CONCEPTS IN MODERN GIFT PACKAGING DESIGN}

Modern gift packaging design mainly conveys folk concepts through folk patterns, folk color, the art of calligraphy, natural materials in order to pass the national cultural characteristics of commodity.

\section{A. Using folk Color to Convey Emotion}

Color is closely related to people's life. It promotes people from material to spiritual consciousness, and it is a kind of visual symbol [3] (P55) that can most stimulate human response in all visual elements. Color plays an important role in the packaging design. It is an important factor to beautify and highlight packaging. The use of packaging color is closely linked with design idea of the whole packaging. Folk color has the characteristics of fullness, richness, intensity and strong symbolism, clear hue, sharp contrast and high saturation. In general, red symbolizes jubilance, auspiciousness and wealth; yellow is the symbol of emperor and power; these two colors give people a sense of nobility, richness and appetite. Modern gift packaging deign for liquor and festival gifts packaging design basically use red, because Chinese folk have a common identity that red represents jubilance, auspiciousness, blessing and gift giving. It is the essence of the folk customs in the thousand years of Chinese culture. At the same time, yellow is a traditional folk color in China, so most of gift packaging for spring festival foods in the market is red and yellow. These two colors greatly exaggerate and adorn festival atmosphere. [3] (p75) For example, the whole packaging for tea and moon gift box designed by Cheng Xiangru, use gold color, like the robe of emperor. Consumers may have a bright new look. Put tea and moon together in the box, which is undoubtedly an extension of Chinese folk customs. The delicious taste of moon and the mellowness of tea are simply for an emperor. The overall hue takes you into the royal realm.

\section{B. The Expression of Blessing in Folk Pattern}

Chinese traditional culture leaves us a lot of beatific and auspicious and beautiful patterns with classic styling, profound implied meaning, such as clouds, dragon and phoenix, watermark, blossoming, goalkeeper, flying to the sky, auspicious patterns and others. These traditional folk patterns have a rich flavor of life and a strong symbolic color, reflecting people's yearning and praying for spiritual life. The traditional folk pattern is highly decorative and with various expressive techniques, and has the characteristics of harmony, symmetry, solemnity, perfection, rigorous style and beauty of form. So this kind of folk patterns as design elements are widely used in modern gift packaging design to convey the rich cultural connotation of gift packaging and arouse consumers' homesickness and convey the sense of trust and intimacy of ancient and natural folk customs. At same time, it can improve the cultural value of gift packaging and reflect design style of designer. For example, the gift packaging of Banchengshaoguo Liquor (Dragon Age) is designed in regular cube and with auspicious clouds in two-dimension series as background. The front left side of packaging is decorated with traditional dragon pattern, leaving us a kind of expansiveness, solemnity and dignity.

\section{Calligraphy Highlighting the National Quality}

Calligraphy is widely used in modern gift packaging. Calligraphic fonts are smooth in artistic conception, vigorous and vivid. It is particular about line of ink, style of structure, expression, blank, the unity of beautiful form and vivid expression, style and charm, which is the embodiment of artistic charm and spiritual style specific in Chinese or Asian culture. It is the most common means to express the simple traditional style and folk quality in modern gift packaging design. It also contains unique spiritual charm in modern gift packaging design. Most of gift packaging designs for liquor directly use calligraphy, with no overmuch pattern, so such packaging is simple, dignified, and strong in visual impact, and reveals the vitality and personality in modern gift packaging design. For example, the gift packaging that Beijing Dongdao Design Co., Ltd. designed for the National Ministry of Culture is simple in style. It uses calligraphy as design element for national gift packaging, showing the national culture.

\section{Natural Materials Reflecting "Humanistic Care"}

The application of packaging materials is an important part in the modern packaging design. The packaging involves the selection of materials. Along with the progress of science and technology, the demand of the consumer market changes frequently and a large number of new packaging materials appear. Types of materials, including natural materials and composite materials, are growing increasingly. On one hand, it can make full use of natural resources by using natural materials as packaging material in modern gift packaging design, which is economic and environmentally friendly. On the other hand, to use natural 
materials, such as bamboo, rattan, leaves, wood and etc., and their natural grains and unique fragrance and simple style could arouse the minds of consumers a natural and plain feelings and a sense of environmental protection, health and kindness and trust. At the same time, different materials can also reflect economic characteristics and folk culture in different regions. For example, the award-winning work of students of 06 "Bamboo-tube Wine Gift Packaging" is an example of using natural material as packaging material and certain technological process to design, giving a simple sense of returning to nature. It well embodies the affinity and "humanistic care" of modern gift packaging.

\section{THE INTEGRATION OF MODERN ELEMENTS AND FOLK ELEMENTS IN GIFT PACKAGING}

In the positioning of modern gift packaging design, customers often want gift packaging with traditional style but without sticking to it. They tend to think that the tradition is old while the modern is lively. The main consumers of the gift package are fashionable young people, so it requires integrating traditional elements and modern elements in gift packaging. It is difficult to determine the "degree" of style between tradition and the modern in modern gift packaging design. However, it is a new thinking and realistic request put forward by the market for modern gift packaging design. "What belongs to the nation belongs to the world". It is a new challenge that how could designers integrate design language of modern style and Chinese traditional folk essence. It is a successful way to establish individual style in modern gift packaging design. It could achieve the goal of better integration of the modern and the folk in gift packaging design to grasp the reasonable degree between them.

\section{REFERENCES}

[1] Zeng Qinlan, Shen Danya. Practice of Packaging Design. Shanghai: Orient Publishing Center, 2008:135.

[2] Gu Minghui. Folk Concepts in Modern Chinese Logo Design. Decoration. 2003.

[3] Yang Min. Packaging Design. Chongqing: Southwestern Normal University press, 2006: 55.

[4] Chen Qinjian. Contemporary Chinese Folklore. Shanghai: East China Normal University Press, 1988.

[5] Yang Zongkui. Taiwan Creative Encyclopedia Packaging Design. Changsha: Hunan Art Press, 2000 